\title{
„Czy więc byliśmy i jesteśmy naiwni...?” \\ Jeszcze jeden głos webacie \\ nad wykorzystaniem relacji ustnych \\ w badaniach najnowszej historii Polski ${ }^{1}$
}

Wśród badaczy akademickich zajmujących się historią mówioną w Polsce, czy szerzej: w gronie „środowiska samoidentyfikującego się jako oral history" ${ }^{\text {"3 }}$ dość długo panował optymizm w kwestii jej wykorzystania w badaniach historycznych. Działo się tak nawet mimo wyraźnej rezerwy wobec oral history wykazywanej przez zdecydowaną większość historyków dziejów najnowszych. Daleko posunięty sceptycyzm tych ostatnich wyrażany był w deklaracjach o charakterze metodologicznym ${ }^{4}$, a przede wszystkim

1 https://orcid.org/oooo-ooo1-7499-7083.

2 Tekst powstał w ramach projektu badawczego pt. „Re-inspekcja źródeł wywołanych”, finansowanego przez Narodowe Centrum Nauki na podstawie umowy nr UMO2015/19/B/HS3/01761.

3 M. Kurkowska-Budzan, Informator, świadek historii, narrator: kilka wątków epistemologicznych $i$ etycznych oral history, „Wrocławski Rocznik Historii Mówionej”, R. 1 (2011), s. 10, 17 .

4 Zob. A. Paczkowski, Historyk dziejów najnowszych wśród źródet, [w:] Historia - dziś. Teoretyczne problemy wiedzy o przeszłości, red. E. Domańska, R. Stobiecki, T. Wiślicz, Kraków 2014, s. 143-16o; J. Eisler, Refleksje nad wykorzystaniem relacji jako źródta $w$ badaniu historii PRL (rozmowy $z$ dysydentami i prominentami), „Polska 1944/45-1989. Studia i materiały”, t. 6 (2004), s. 23-48. 
znajdował odzwierciedlenie w relatywnie niewielkiej liczbie publikacji wykorzystujących w praktyce historię mówioną. Nie przeszkadzało to jednak upatrywać w oral history czynnika wzbogacającego obraz przeszłości albo inspirującego formułowanie alternatywnych jej interpretacji. Jako obszar eksploracji wskazywano zagadnienia umykające uwadze źródeł aktowych, takie jak historia życia codziennego, mentalności czy historia prywatności ${ }^{5}$. Mocnym oparciem dla nadziei, jakie wiązano i nadal jeszcze wiąże się z historią mówioną, stały się imponujące kolekcje relacji ustnych, ze zbiorami Ośrodka KARTA/Domu Spotkań z Historią na czele.

Wydaje się jednak, że w ostatnich latach ów optymizm zaczyna z wolna ulatywać. Historia mówiona doszła bowiem w swoim akademickim wydaniu do punktu, w którym rosnące archiwa przestają nieść nadzieję, a stają się wręcz wyrzutem sumienia dla propagatorów ich wykorzystania w interpretacjach i rekonstrukcjach przeszłości. Przyrost zgromadzonych w nich relacji potęguje zaś poczucie dyskomfortu, przechodzącego niekiedy w irytację: miały przecież stać się czynnikiem przekształcającym praktykę badań historycznych albo przynajmniej w znacznym stopniu wpływać na repertuar pytań badawczych. Nic takiego jednak się nie stało.

Sytuacja ta prowokuje za to do retrospektywnych ocen czy podsumowań, których najlepszym przykładem jest wypowiedź Piotra Filipkowskiego podczas panelu „Historia mówiona w Polsce”, zorganizowanego w ramach konferencji „Oral History in Central-Eastern Europe: Current Research Areas, Challenges and Specificity" (Łódź, 17-18 IX 2015 r.), którego tezy zostały opublikowane na łamach „Wrocławskiego Rocznika Historii Mówionej”. Filipkowski występuje tu w podwójnej roli: badacza, którego naukowa kariera jest związana z historią mówioną, oraz rzecznika twórców archiwów oral history (jako współtwórca Archiwum Historii Mówionej Ośrodka

5 D. Kałwa, Kozetka historyka: oral history w badaniach życia prywatnego, [w:] Rodzina - prywatność - intymność. Dzieje rodziny polskiej w kontekście europejskim. Sympozjum na XVII Powszechnym Zjeździe Historyków Polskich (Kraków 15-18 września 2004). Zbiór studiów, red. D. Kałwa, A. Walaszek, A. Żarnowska, Warszawa 2006, s. 181-190.

6 W dyskusji oprócz P. Filipkowskiego wzięli udział także: Marta Kurkowska-Budzan, Anna Wylegała oraz Marcin Jarząbek, zob.: P. Filipkowski [et al.], Historia mówio$n a w$ Polsce. Głosy $w$ dyskusji (podczas konferencji „Oral History in Central-Eastern Europe: Current Research Areas, Challenges and Specificity”, Łódź, 17-18 września 2015 r.), „Wrocławski Rocznik Historii Mówionej”, R. 5 (2015), s. 293-308. 
KARTA/Domu Spotkań z Historią). I to przede wszystkim ta druga tożsamość skłania go do gorzkiego zestawienia nadziei, jakie towarzyszyły autorom kolekcji, z realiami ich funkcjonowania w charakterze składnika refleksji nad przeszłością, w tym w szczególności w badaniach historycznych. Podsumowując niewesołe wnioski, powiedział: „Czy więc byliśmy i jesteśmy naiwni gromadząc, nieraz nakładem dużego wysiłku i sporych wydatków, dziesiątki, setki i tysiące nagrań w przekonaniu, że staną się cennym materiałem badawczym, ważnymi historycznymi źródłami?”7.

Przywołuję te słowa dlatego, że obrazują trend obserwowany od niedawna w polskim środowisku oral history: zapał pionierów ustępuje miejsca dojrzałym pytaniom o to, co rodzima historia mówiona osiągnęła, w jakim punkcie się znajduje oraz dokąd zmierza. Charakterystyczne, że pytania przestają mieć charakter otwarty - towarzyszą im mniej lub bardziej kategoryczne odpowiedzi albo przynajmniej oczekiwania rozstrzygnięć. Dzieje się tak być może dlatego, że pytania te motywowane są troską i autentycznym niepokojem o przyszłość oral history w ramach nauki, a w szczególności w ramach historiografii. Nie są to już jedynie dylematy dyskutowane w kuluarach czy komentarze wygłaszane w czasie branżowych konferencji. W ostatnich latach zyskały one swoje odzwierciedlenie w co najmniej kilku tekstach, które w większym lub mniejszym stopniu odnoszą się do szerszego korpusu całkiem już bogatej polskiej refleksji teoretycznej i metodologicznej nad oral history.

W niniejszym artykule chciałbym bezpośrednio nawiązać do tej nabierającej tempa i - nade wszystko - potrzebnej debaty. W centrum zainteresowania stawiam problem historii mówionej jako elementu klasycznie pojętej praktyki historiograficznej, czyli „procesu badawczego zmierzającego w drodze odpowiedniego krytycznego badania źródeł do uzyskania prawdy o przeszłości (prawdy w ujęciu arystotelesowskim), której zasadniczym komponentem jest chronologia, traktowana jako historyczne datowanie"8. Problem będzie rozważany na podstawie pytania granicznego: czy historia mówiona, w swojej obecnej postaci (tzn. biorąc pod uwagę jej teoretyczne, praktyczne oraz instytucjonalne usytuowanie) ma realną szansę na odegranie znaczącej roli w kształtowaniu

Ibidem, s. 294-295.

$8 \quad$ M. Kurkowska-Budzan, Ile cukru w cukrze, czyli ile historii $w$ historii mówionej?, [w:] Klio na wolności. Historiografia dziejów najnowszych po 1989 roku, red. M. Kruszyński [et al.], Lublin 2016, s. 117. 
praktyki historiograficznej w Polsce. I w jakim zakresie pojawiające się propozycje dają nadzieję na uczynienie z oral history czynnika dostarczającego wartościowych poznawczo interpretacji przeszłości; w jakim stopniu stać się one mogą nowym impulsem do badań historycznych, prowokując do zadawania nowych pytań i sugerując nieszablonowe odpowiedzi.

\section{Sila archiwum}

Postulat pisania „innej historii” towarzyszył narodzinom oral history, znajdując swoją pierwszą pełną emanację w The Edwardians Paula Thompsona9. Jak zauważa Marta Kurkowska-Budzan: „[Oral history] pojawiła się w latach 70. jako kolejna «nowa historia» $\mathrm{z}$ ambicjami odegrania roli zwycięskiego paradygmatu w historiografii, a zarazem jako ruch społeczny"10. Powstawała zatem w swojej zachodnioeuropejskiej odsłonie jako swoista przeciw-historia. Oddawano w niej głos „zwykłym ludziom” nie tylko po to, by ich upodmiotowić, ale też by przełamać monopol archiwum na ustanawianie obrazów przeszłości. Paul Thompson przekonywał w swojej książce-manifeście The Voice of the Past:

To właśnie możliwość nowego, odmiennego podejścia do świadectw przeszłości wydaje się z perspektywy istniejących rodzajów pisarstwa historycznego najważniejszym elementem historii mówionej [...] Nie ma wątpliwości, że takie podejście prowadzi do bardziej realistycznej rekonstrukcji przeszłości. Otaczająca nas rzeczywistość jest złożona i wielostronna. Podstawową zaletą historii mówionej jest to, że umożliwia owej złożoności i pierwotnej różnorodności stanowisk pełną reprezentację, w większym stopniu niż w przypadku użycia innych źródeł ${ }^{11}$.

W znanym artykule Alistaira Thomsona pojawienie się historii mówionej jako projektu pozostającego $\mathrm{w}$ kontrze do zastanych metod badania przeszłości, a zarazem na wskroś historycznego, wyznacza jeden z czterech podstawowych zwrotów paradygmatycznych w dziejach metody, ustanawiając jednocześnie pewien wzorzec jej uprawiania na kolejne dekady ${ }^{12}$. Ten etap

$9 \quad$ P. Thompson, The Edwardians. The Remaking of British Society, London 1975.

10 M. Kurkowska-Budzan, Historia zwyktych ludzi. Wspótczesna angielska historiografia dziejów społecznych, Kraków 2003, s. 177-178.

11 P. Thompson, Głos przeszłości. Historia mówiona, [w:] Teoria wiedzy o przeszłości na tle wspótczesnej humanistyki. Antologia, red. E. Domańska, Poznań 2010, s. 286-287.

12 A. Thomson, Four Paradigm Transformations in Oral History, „The Oral History Review", t. 34 (2007), nr 1, s. 49-70. 
rozwojowy w polskiej historii mówionej w zasadzie nie zaistniał ${ }^{13}$. Innymi słowy historia mówiona w Polsce, rozumiana jako metoda dotarcia do przeszłej rzeczywistości, nie miała swojego „kamienia węgielnego” - takiego punktu odniesienia (na przykład „kanonicznej” monografii naukowej, w rodzaju pracy Paula Thompsona), który zapewniłby jej tożsamość w ramach nauki historycznej.

Stało się tak w przede wszystkim dlatego, że zbieranie i wykorzystywanie relacji - zarówno na poziomie deklaracji programowych, jak i w praktyce badawczej polskich historyków dziejów najnowszych - zasadniczo abstrahowało od tradycji zachodnioeuropejskiej oral history. Celem pionierów tej mody, takich jak Krystyna Kersten, Tomasz Strzembosz czy nieco później Jerzy Eisler, nie było oddanie głosu grupom nieuprzywilejowanym ani pisanie "history from below”. Motywacja etyczna, jakkolwiek obecna w tej refleksji, schodziła na dalszy plan, zaś pierwszorzędne znaczenie miał walor poznawczy pozyskiwanego materiału. Chodziło przede wszystkim o wypełnianie „białych plam” informacjami niedostępnymi w innych źródłach. Podejście prezentowane przez polskich pionierów stosowania wywiadów w badaniach przeszłości nie mieściło się zatem w żadnym z dwóch zaproponowanych przez Michaela Frischa, i zakorzenionych w zachodniej oral history, schematów: nie było to ani more-history, ani anti-history. Najwłaściwszy na określenie tego zjawiska w Polsce wydawałby się chyba konstrukt „zamiast-historii”.

W gruncie rzeczy problematyczne jest jednak w ogóle określanie tej praktyki badawczej mianem „oral history”. Nie przynosiła ona bowiem w Polsce znaczącego - porównywalnego z tym obserwowanym w historiografii anglosaskiej - przesunięcia w obrębie dominującego paradygmatu naukowego: ani w obrębie stosowanej metodologii, ani w zakresie tematów badań. Nie wykazywała też autonomii w ramach historiografii czy zdolności do przekształcania narracji. Zresztą a mbicje polskich historyków zdecydowanie nie szły też w tym kierunku. Najlepszym być może na to dowodem jest stosowana terminologia - na określenie pozyskiwanych na potrzeb procesu badawczego relacji ukuto pojęcie „źródła wywołanego”. Nie jest to

13 Jest to element szerszego zjawiska, wynikającego głównie z relatywnie późnego upowszechnienia się historii mówionej w Polsce. Jak zauważa Piotr Filipkowski, polska oral history nie przeszła drogi paradygmatycznych przekształceń, która była udziałem jej zachodnioeuropejskiej wersji. 
bynajmniej synonim pojęcia „oral history”. Należałoby w nim raczej widzieć semantyczny przejaw udanej próby wchłonięcia niestandardowej metody pozyskiwania danych przez tradycyjnie pojęty warsztat historiografii, dla którego elementem centralnym było i pozostaje archiwum, rozumiane jako zbiór źródeł aktowych.

Pierwszym praktykom „źródła wywołanego” (zwykle byli to badacze historii politycznej) nie w głowie było bowiem wywracanie porządku źródeł ustalonego przez klasyków dziewiętnastowiecznej historiografii. Wywiady zastępowały im po prostu niedostępne archiwalia. Taki był na przykład kontekst badań Tomasza Strzembosza dotyczących Polskiego Państwa Podziemnego. Strzembosz od 1960 r. przeprowadził około dwóch tysięcy rozmów z kilkuset osobami. Po latach swój niezwykły wysiłek badawczy komentował następująco:

Nieomal wszystkie moje przygody i silniejsze przeżycia, wywołane badaniem dziejów najnowszych Polski, związane są ze zbieraniem relacji czy - jak wolą inni - wywiadów. Metoda ta, przez dawniejszych historyków zaniedbywana i dotąd - niesłusznie - niedoceniana, w sytuacji badawczej lat 1960-1980 była absolutną koniecznością. Brak nawet podstawowych dokumentów dotyczących organizacji podziemnych, w tym największych, jak AK, BCh, NOW czy NSZ, i niedostępność tysięcy zespołów archiwalnych, ukrytych przed nie powiązanymi z partią komunistyczną zawodowymi badaczami skazywało ich na korzystanie z wyborów i odpisów, sporządzanych przez ludzi „«właściwych» [...] Jeżeli chciało się coś uczynić dla wyświetlenia przynajmniej podstawowych i niecenzuralnych zagadnień - trzeba było prosić o rozmowę i rozmawiać ${ }^{14}$.

Podobne podejście do relacji prezentował Jerzy Eisler w swojej wydanej w 1991 r. pracy Marzec 1968. Geneza, przebieg, konsekwencje $e^{15}$. Tu także

14 T. Strzembosz, Z przygód historyka polskiej konspiracji wojskowej 1939-1945, [w:] Ojczyzna $i$ wolność. Prace ofiarowane Profesorowi Janowi Ziótkowi w siedemdziesiata rocznicę urodzin, red. A. Barańska, W. Matwiejczyk, E. Ziółek, Lublin 200o, s. 681. Por.: idem, Oddziaty szturmowe konspiracyjnej Warszawy 1939-1945, Warszawa 1979; idem, Szare Szeregi jako organizacja wychowawcza, Warszawa 1981; idem, Akcje zbrojne podziemnej Warszawy 1939-1945, Warszawa 1978; idem, Odbijanie i uwalnianie więźniów w Warszawie 1939-1944, Warszawa 1972.

15 J. Eisler, Marzec 1968. Geneza, przebieg, konsekwencje, Warszawa 1991. Por.: D. Kałwa, Historia mówiona w polskich badaniach dziejów najnowszych, „Wrocławski Rocznik Historii Mówionej", R. 7 (2017), s. 163-183. 
wywiady były środkiem do uzyskania wiedzy o wydarzeniach z przeszłości, a ich wykorzystanie podyktowane było koniecznością.

Badania z wykorzystaniem „źródeł wywołanych” podejmowane jeszcze przed 1989 r. przez historyków takich jak Strzembosz, Eisler czy Jan Ciechanowski przyjmowały, jak zauważa Dobrochna Kałwa, postać „historycznego śledztwa”. Bezpośrednią inspiracją takiego rodzaju badań była praktyka sądowa, skupiająca się na analizowaniu akt (Kałwa podkreśla przy tym, że dostarczały one głównie wiedzy zdroworozsądkowej dotyczącej technik przesłuchiwania, niekonfrontowanej z dorobkiem innych nauk, np. psychologii) ${ }^{16}$. Dla historyków dziejów politycznych otwarcie archiwów (w szczególności dostęp do akt PZPR, a potem także aparatu represji PRL), które dokonało się po 1989 r., oznaczało albo zminimalizowanie roli relacji ustnych, albo całkowite ich wyeliminowanie na rzecz akt traktowanych jako bardziej wiarygodne.

Najbardziej interesujące jest jednak nie generalne uznanie przez historyków dziejów politycznych prymatu „źródła pisanego" nad „źródłem wywołanym”, ale trwałość tego trendu w odniesieniu do całości historiografii dziejów najnowszych. A ta przecież, mimo dominacji tematyki politycznej, jest jakościowo bardzo zróżnicowana. I chociaż współcześnie obserwować można wzrost zainteresowania relacjami jako źródłem par excellence, szczególnie w przypadku historii społecznej PRL, to jednocześnie nie równa się to zakwestionowaniu czy przynajmniej próbom podważenia prymatu archiwum w badaniach przeszłości. Przy czym nie chodzi mi o całkowite rezygnowanie z archiwaliów, ale o takie podejście, które z akt wytworzonych przez instytucje państwowe nie czyni głównego elementu sterującego narracją ani jej podstawowego budulca.

W ostatnich latach opublikowano co najmniej kilka bardzo wartościowych prac, których autorzy wykorzystują nagrane relacje. Szczególne zainteresowanie metodą wykazują historycy społeczni lub ci, którzy w swoich dociekaniach starają się uwzględniać dorobek nauk społecznych ${ }^{17}$. To ciągle

16 Dobrochna Kałwa tę grupę historyków nazwie „pierwszym paradygmatycznym pokoleniem oral history w Polsce”; zob.: ibidem, s. 165.

17 E. Szpak, Mentalność ludności wiejskiej w PRL. Studium zmian, Warszawa 2013; D. Jarosz, Mieszkanie się należy. Studium z peerelowskich praktyk społecznych, Warszawa 2010; N. Jarska, Kobiety $z$ marmuru: robotnice $w$ Polsce $w$ latach 1945-196o, Warszawa 2015; A. Machcewicz, Bunt. Strajki w Trójmieście. Sierpień 1980, Gdańsk 2015; M. Kurkowska-Budzan, M. Stasiak, Stadion na peryferiach, Kraków 2016; D. Jarosz, G. Miernik, „Zhańbiona” wieś Okót: opowieść o buncie, Warszawa-Kielce 2016. 
pojedyncze przypadki, ale z drugiej strony tytuły ważne, będące przedmiotem debat i polemik. Tyle tylko, że i one są, pod względem źródłowym, zaprojektowane konwencjonalnie. Wywiady czy ich fragmenty jako składnik narracji występują w nich głównie w roli uzupełnienia dla konstrukcji zbudowanej na podstawie materiałów archiwalnych, ewentualnie pełnią funkcję ilustracyjną $a^{18}$. Otrzymujemy zatem publikacje ciekawe i w swoich ustaleniach nowatorskie, ale jednocześnie hierarchizujące źródła w sposób bardzo tradycyjny ${ }^{19}$.

Pouczająca jest lektura wstępów metodologicznych do tych prac. Omówienie podstawy źródłowej w każdym przypadku rozpoczyna się od charakterystyki źródeł aktowych, czemu towarzyszy czasem także deklaratywne podkreślenie ich wagi. Tak na przykład czyni Anna Machcewicz w swojej książce Bunt. Strajki w Trójmieście. Sierpień 1980. Opis wykorzystanych materiałów rozpoczyna od zdania: „Główną podstawą książki są materiały archiwalne" ${ }^{20}$. Zwykle w pracach naukowych w spisie wykorzystanych zbiorów archiwalnych występuje jasna gradacja: im wyższa instancja władzy, tym większa szansa, że wytworzone przez nią akta znajdą się na szczycie hierarchii źródeł. Z kolei relacje ustne umieszczane są na końcu wykazu wykorzystanych materiałów. Zabieg ten wiele mówi o przypisywanej im przez autora roli w rekonstrukcjach przeszłości. Jeszcze dobitniej ich niską rangę odzwierciedlają czynione niekiedy zastrzeżenia dotyczące wiarygodności wywiadów, jako opartych na zawodnej ludzkiej pamięci ${ }^{21}$. Niepewność związaną z użyciem historii mówionej w narracji historycznej

18 Zob. np.: E. Szpak, „Chory człowiek jest wtedy jak coś go boli”. Spoteczno-kulturowa historia zdrowia i choroby na wsi polskiej po 1945 r., Warszawa 2016., s. 16. O zjawisku „ilustracyjnego" użycia oral history zob. uwagi Marty Kurkowskiej-Budzan podczas wspomnianej debaty „Historia mówiona w Polsce”, P. Filipkowski [et al.], Historia mówiona w Polsce..., s. 300.

19 Ciekawe są w tym kontekście obserwacje Agaty Stolarz, która rozpoznaje właśnie takie dwa zasadnicze użycia historii mówionej w ramach historiografii: ilustracyjne i uzupełniające. W kontekście tego drugiego zastosowania na szczególną uwagę zasługuje dokonanie przez autorkę omówienie metody pracy Andrzeja Friszke w jego pracy Anatomia buntu. Kuroń, Modzelewski i komandosi, zob.: A. Stolarz, Dzielenie się pamięcia. Praktyka i teoria historii mówionej, Lublin 2016, s. 200-211; por. A. Friszke, Anatomia buntu. Kuroń, Modzelewski i komandosi, Kraków 2010.

20 A. Machcewicz, op. cit., s. 16.

${ }^{21}$ Zob. np.: E. Szpak, Mentalnośc ludności wiejskie..., s. 18; D. Jarosz, G. Miernik, op. cit., s. 18 . 
i jej „nieprzystawalność” do klasycznie (źródłowo) zorientowanych badań najlepiej chyba oddają słowa Machcewicz z przytaczanego wstępu, odnoszące się do specyfiki użycia „źródeł wywołanych”: „Wytworzone w ten sposób źródła muszą jednak podlegać krytyce zgodnej z wymogami warsztatu, do którego podstawowych zasad należą sceptycyzm i weryfikowanie wszystkich uzyskanych informacji poprzez konfrontację z innymi materiałami"22.

Mamy tu zatem do czynienia z przypomnieniem podstawowych zasad pracy historyka: to wszak na podejrzliwości i krytycznym podejściu do śladów przeszłości, na bezustannym sprawdzaniu informacji „przesyłanych” przez przeszłość w źródłach ufundowany został gmach nowoczesnej historiografii $^{23}$. Symptomatyczne jednak, że autorka czuje się w obowiązku przypomnieć ów elementarz warsztatu właśnie w kontekście relacji ustnych, a podobna myśl nie towarzyszy jej w odniesieniu do materiałów aktowych, których wspomniany przez nią sceptycyzm dotyczy w takim samym przecież stopniu.

Historia mówiona w dalszym ciągu pozostaje w warsztacie polskiego historyka dziejów najnowszym narzędziem nowym i w gruncie rzeczy nieprzyswojonym. Nawet jeśli poszczególni autorzy deklarują „stosowanie metody oral history", w praktyce poruszają się zwykle w obrębie ustalonego historycznego warsztatu. Inspiracje czerpią z lokalnej tradycji „źródła wywołanego", która oznacza najczęściej transplantację krytyki źródła (aktowego) na proces tworzenia i analizy wywiadu. Bezwzględną ocenę niezdolności historyków do refleksji metodologicznej w odniesieniu do wykorzystania relacji ustnych wystawił Filipkowski, kiedy, zachęcając w swoim ważnym artykule sprzed kilku lat do odkrycia źródłowego potencjału oral history, wykreśla ich z listy adresatów apelu:

To „my”, które tutaj projektuję, dotyczy zresztą przede wszystkim socjologów i antropologów (etnografów, kulturoznawców), w znacznie mniejszym stopniu historyków. Nawet jeśli ci ostatni powołują się na „klasyczny” tekst Krystyny Kersten ${ }^{24}$

22 A. Machcewicz, op. cit., s. 18.

23 Por. wypowiedź M. Kurkowskiej-Budzan podczas debaty „Historia mówiona w Polsce”: P. Filipkowski [et al.], Historia mówiona w Polsce..., s. 303.

24 Na przełomie lat 6o. i 70. XX w. ukazały się dwa teksty Krystyny Kersten dotyczące „źródła wywołanego”. Pierwszy, na który powołuje się Filipkowski, jest zapisem jej wystąpienia wygłoszonego podczas X Powszechnego Zjazdu Historyków Polskich w Lublinie w 1968 r., drugi stanowi usystematyzowaną i rozwiniętą wersję wystąpienia i ukazał się 
z lat sześćdziesiątych ubiegłego wieku, zachęcający do korzystania ze źródeł wywołanych w badaniach historycznych (co oczywiście nie jest jeszcze w pełni tożsame z historią mówioną), pokazując metodologiczną żywotność, samodzielność i otwartość rodzimej historiografii, to trudno im zbudować ciąg dalszy tej opowieści. A jeszcze trudniej wskazać przykłady konkretnych prac historycznych, które zrywałyby z przywiązaniem do badań archiwalnych i dokumentów pisanych ${ }^{25}$.

Trudno się z diagnozą Filipkowskiego nie zgodzić. Zresztą, w takiej ocenie sytuacji nie jest on odosobniony ${ }^{26}$. Lecz przecież problem, jaki porusza, nie ogranicza się jedynie do braku metodologicznego wyrafinowania historyków-praktyków oraz ich przywiązania do archiwum. Drugą stronę medalu stanowi bezradność samej historii mówionej i badaczy z nią związanych wobec przeszłej rzeczywistości. Nie jest więc tylko tak, że to historycy w Polsce nie zauważają oral history. Mamy także do czynienia z działaniem symetrycznym: historii mówionej również gdzieś umyka historia. Jak słusznie zauważa Filipkowski, zwracając się do polskiego środowiska oral history: „Nie nadbudowujemy naszych praktyk dokumentacyjnych, naszych analiz i naszego teoretyzowania o historii mówionej na solidnym fundamencie badań historycznych, które opierałyby się na źródłach wywołanych, na relacjach świadków"27.

Jednak przyczyn tego stanu rzeczy nie można, jak chce autor cytowanych słów, zredukować do wybiórczego czy chaotycznego czerpania z tradycji zachodniej oral history, do wykorzystywania wątków z jej bogatego

w „Kwartalniku Historycznym” trzy lata później. Zob.: K. Kersten, Relacje jako typ źródła historycznego, [w:] Pamiętnik X Powszechnego Zjazdu Historyków Polskich w Lublinie 17-21 września 1968 r. Referaty plenarne. Sekcje VII-XI, Warszawa 1968, s. 316-329; eadem, Historyk - twórcq źródet, „Kwartalnik Historyczny”, 1971, nr 2, S. 313-329.

P. Filipkowski, Historia mówiona jako historia faktyczna albo jak „odantropologizować” opowieści o przeszłości?, „Rocznik Antropologii Historii”, R. 5 (2015), s. 100.

26 D. Kałwa, Kozetka historyka..., s. 181; M. Kierzkowski, Źródta ustne (audiowizualne) w kontekście badań historycznych. Próba metodologicznego ogladu statusu relacji ustnych, Wrocław 2008, http://biblioteka.teatrnn.pl/dlibra/dlibra/ doccontent?id=25574 (dostęp: 4 VII 2018 r.); M. Kurkowska-Budzan, Informator, świadek historii, narrator...

27 P. Filipkowski, Historia mówiona jako historia faktyczna..., s. 99. 
teoretycznego dorobku, które akurat pasują do prowadzonych badań ${ }^{28}$. Tło jest znacznie bardziej złożone, choć, paradoksalnie, charakteryzuje się wysokim stopniem uporządkowania.

Niezadowalający stan obecny, czyli niezdolność polskiej oral history do zaproponowania atrakcyjnych poznawczo i alternatywnych dla istniejących rekonstrukcji/interpretacji przeszłości, w znacznym stopniu uwarunkowany jest jej drogą rozwojową i tym, na jakich fundamentach metodologicznych ją oparto. Tu zaś mamy do czynienia ze stopieniem się inspiracji płynących z zachodniego pierwowzoru z lokalnymi uwarunkowaniami.

\section{Cień kolekcji}

Historia mówiona, rodząc się w Polsce na przełomie lat 80. i 90. XX w., wkraczała w przestrzeń opuszczaną przez historyków. Ich idea „źródła wywołanego" popadała tymczasem w koncepcyjny marazm lub w ogóle była porzucana na rzecz otwierających swoje wrota znacznie szerzej archiwów z nieprzebranymi zasobami niedostępnych wcześniej akt i obietnicą dotarcia do prawdy o minionej epoce. Zanim obszar pozostawiony przez historyków odkryli przedstawiciele innych dyscyplin, został on zasiedlony przez twórców oddolnych, obywatelskich inicjatyw dokumentacyjnych. Zainicjowanie planowych, metodycznych działań związanych z gromadzeniem relacji datuje się w Polsce na koniec lat 8o. To wtedy (1987 r.) środowisko warszawskiej KARTY rozpoczęło nagrywanie wywiadów w ramach "Archiwum Wschodniego”. Nie bez przyczyny ten właśnie moment uznaje się za przełomowy, a działania KARTY za „akt założycielski” polskiej oral history. Niosły one ze sobą właściwy historii mówionej w jej wersji zachodniej ładunek kontestatorski, lecz była to specyficznie ukierunkowana „kontr-historia”. Za swój cel pierwsi praktycy, podobnie zresztą jak w innych krajach postkomunistycznych, obrali sobie sprzeciw wobec przekłamań dokonywanych przez komunistyczne reżimy oraz dążenie do wypełniania „białych plam” (i w tym sensie ich działania przypominały te podejmowane przez wspomnianych wcześniej Tomasza Strzembosza czy Jerzego Eislera). W efekcie, jak podsumowuje Dobrochna Kałwa, która wyczerpująco scharakteryzowała przed kilkoma laty rodowód środkowoeuropejskiej „historii mówionej":

28 Ibidem, s. 99-100. 
[...] historia mówiona w tym regionie była w swoich początkach historią polityczną, ponieważ postulat oddania głosu grupom wykluczonym - jeden z fundamentów historii mówionej - oznaczał, inaczej niż w krajach zachodnich demokracji, oddanie głosu przedstawicielom elit politycznych, intelektualnych i kulturalnych, represjonowanych, zmarginalizowanych lub wykluczonych z dominującego dyskursu ${ }^{29}$.

Szlaki przecierała KARTA, ale wkrótce znalazła licznych naśladowców. Rozległe kolekcje stały się bez wątpienia najlepiej rozpoznawalnym składnikiem pejzażu polskiej historii mówionej, a twórcy zbiorów mieli istotny wpływ na jej oblicze ${ }^{30}$. Szybko jednak przestała to być twarz buntownika. Stało się tak między innymi dlatego, że zasadniczy wysiłek tworzenia jej zasobów przypadł już na czas po przełomie ustrojowym. I w tych zmienionych warunkach przekształceniu uległa także funkcja kolekcji. Generalnie rzecz biorąc, spełniały one nowe oczekiwania, często odgórne w takim samym stopniu, jak oddolne. Nowy start wymagał nowego układu odniesienia. Jak oceniała Anna Wolff-Powęska: „Wzrosło zapotrzebowanie na nowe mity fundacyjne jako uzasadnienie więzi i tożsamości narodów w nowych warunkach demokracji. Uwolnione od cenzury społeczeństwa dokonują rewizji historycznych. Miasta i miasteczka odzyskują swoją wielobarwną historię"31.

Tak pojęta historia mówiona była z całą pewnością wartościowa poznawczo, a jej użycie, poprzez zwrócenie uwagi na doświadczenia ofiar totalitaryzmów, miało niepodważalny walor etyczny. Jednak w polu epistemologicznym, które z punktu widzenia profesjonalnych badań historycznych jest istotniejsze, oral history nie wywołała w Polsce rewolucji na miarę swojego zachodnioeuropejskiego pierwowzoru.

D. Kałwa, Historia mówiona w krajach postkomunistycznych. Rekonesans, „Kultura i Historia", nr 18 (2010), http://www.kulturaihistoria.umcs.lublin.pl/archives/1887 (dostęp: 4 VII 2018 r.).

30 Po części zdecydował o tym rozmach podejmowanych przedsięwzięć. Czołowa i wyznaczająca trendy instytucja - Archiwum Historii Mówionej Ośrodka KARTA/ Domu Spotkań z Historią - zgromadziła jak dotąd imponującą liczbę około 5 tys. relacji, a w jego ślad poszły inne podmioty - zarówno ogólnopolskie, jak i te o znaczeniu regionalnym. Bogatymi zbiorami pochwalić mogą się dziś: Ośrodek „Brama Grodzka - Teatr NN” z Lublina, Muzeum Powstania Warszawskiego, Instytut Pamięci Narodowej, Muzeum Historii Żydów Polskich POLIN czy Muzeum Emigracji w Gdyni.

31 A. Wolff-Powęska, Polskie spory o historię i pamięć. Polityka historyczna, „Przegląd Zachodni", 2007, nr 1, s. 5. 
Nie negując wartości istniejących zbiorów relacji, warto zauważyć, że ich zdolności do przekształcania dyskursu historii najnowszej są dość mocno ograniczone. Przegląd projektów dokumentacyjnych, realizowanych przez różnego typu instytucje, w szczególności te czołowe, przekonuje, że już na etapie wytworzenia relacji mamy do czynienia z bardzo silną prefiguracją ewentualnego pola badawczego. Bo choć opisując znaczenie relacji oral history, często podkreśla się unikalność przekazywanego w nich doświadczenia, to autorytet, jakim zwykle obdarza się tzw. „świadków historii” ${ }^{32}$, rzadko ma źródło w tej jednostkowości. W polu epistemologicznym o wadze świadectwa decyduje dokładne przeciwieństwo indywidualności doświadczenia - szeroki historyczny kontekst. Reguły wiązań faktów bazowych albo kształt konstruowanych w opowieści ciągów przyczynowo-skutkowych nie są wyłącznie dziełem rozmówcy ani nawet skutkiem interakcji. W dużej mierze warunkuje je sam przedmiot zainteresowania, a tu tłem nieodmiennie są tematy czy struktury o dużym zasięgu, zaczerpnięte przy tym, co charakterystyczne, z „wielkiej historii”, i często motywowane historią polityczną ${ }^{33}$. W ten sposób zadaniem historii mówionej staje się

32 Samą figurę „świadka historii” można uznać za fundamentalną metaforę opisywanego tu podejścia. Jak zauważyła Marta Kurkowska-Budzan, w jego postaci stopieniu ulegają wspomniane w tekście dwa kluczowe dla historii mówionej i opisane swego czasu przez Michaela Frischa nurty - more-history (więcej historii) i anti-history (przeciw-historii). W tym pierwszym (epistemologicznym) sensie „świadek historii” miał nam pomóc likwidować przemilczenia właściwe peerelowskiej historiografii, tym samym odgrywając rolę szczególnego źródła historycznego. W drugim z przytoczonych sensów (etycznym) to jemu oddawano sprawiedliwość - odzyskiwał odebrane przez komunistyczny reżim prawo opowiedzenia o swojej trudnej przeszłości lub krzywdzie, jakiej doświadczył. Powiązanie tych dwóch obszarów było i pozostaje niezwykle trudne. Jak przekonuje Kurkowska-Budzan w odniesieniu do świadka historii, „krytyka źródła, któremu powinno podlegać jego «świadectwo», jeśli weźmiemy nasz kontekst kulturowy, [...] wydaje się moralnie niezręczna”, M. KurkowskaBudzan, Ile cukru w cukrze..., s. 120. Zob.: M. Frisch, A Shared Authority: Essays on the Craft and Meaning of Oral History, Albany-New York 1990.

33 Trafnie opisała tę właściwość projektów dokumentacyjnych realizowanych w Polsce Marta Kurkowska-Budzan: „Są to lekcje historii, takie jak: II wojna światowa, wywózki na Syberię, Zagłada Żydów, opozycja w Peerelu, życie codzienne w różnych okresach najnowszych dziejów Polski itp. Świadek historii będący bohaterem takiego projektu, nie jest jednak w pełni odpowiedzialny za swoją relację. O tym, co widział lub przeżył, o tym, o czym zaświadcza, zdecydował już ktoś inny. «Na czym polegały pani zadania łączniczki w Powstaniu?», «czy pamięta pan pierwszy dzień po wojnie?» 
uprawomocnianie szerszych i już ustalonych pakietów wiedzy. I nie chodzi tu nawet o jakieś siłowe wtłaczanie jednostkowej narracji w obręb tych większych, ale o to, że te rozleglejsze dyskursy wyznaczają układy odniesienia dla pojedynczych wspomnień, oddziałując na ich treść. W ten sposób etyczne upodmiotowienie „świadka historii” ufundowane jest na epistemologicznym uprzedmiotowieniu, a przynajmniej podległości wobec „dużych narracji”34. W konsekwencji sposób konstruowania przyrastających z roku na rok zbiorów relacji wprawdzie nie blokuje definitywnie kwestionowania ustalonych rekonstrukcji przeszłości, niemniej znacznie taką możliwość ogranicza.

\section{Urok opowieści}

Dominująca pozycja instytucji tworzących kolekcje i idące za tym znaczenie przypisywane gromadzeniu relacji miały także inny skutek dla metodologicznego oblicza akademickiej historii mówionej: zaowocowały mocnym zainteresowaniem samym procesem ich tworzenia. Zagadnienie interakcji na linii badacz-rozmówca stało się jednym z podstawowych punktów metodologicznej refleksji w obrębie polskiej oral history.

Skupienie się na dialogicznym wymiarze historii mówionej znajduje swoje odzwierciedlenie w jej ujęciach definicyjnych. Przeważają tu definicje, które za Michałem Kierzkowskim nazwać można „procesualnymi”"35, z wyeksponowanym $\mathrm{w}$ nich etapem samego pozyskiwania relacji ${ }^{36}$. Tendencja,

- historyk zadający takie pytania chce przede wszystkim ujawnić w kolejnej odsłonie - wersji świadka, wydarzenia lub fragmenty wydarzeń ze zdefiniowanej przez gildię historyków puli tego, co zwiemy faktami historycznymi”, M. Kurkowska-Budzan, Informator, świadek historii, narrator..., s. 20.

$34 \quad$ Eadem, Ile cukru w cukrze..., s. 121.

M. Kierzkowski, Historia mówiona - próba definicji pojęcia, „Wrocławski Rocznik Historii Mówionej", R. 4 (2014), s. 7.

36 Prawdopodobnie najlepszym przykładem jest sygnalizowana już definicja Piotra Filipkowskiego, który specyfikę historii mówionej scharakteryzował następująco: "Gdy mowa dziś o oral history, chodzi z reguły o nagrywanie, archiwizowanie i analizowanie wywiadów (relacji) z uczestnikami / świadkami przeszłych wydarzeń. Można się zgodzić na nieco ściślejszą definicję, wedle której oral history to samoświadoma, poddana pewnej dyscyplinie rozmowa między dwoma ludźmi na temat niektórych aspektów (doświadczonej) przeszłości uważanych za historycznie istotne, prowadzona z zamiarem jej zarejestrowania. Komunikacja ta, choć przybiera postać relacji, pozostaje dialogiem - jej forma i treść zależą od pytań (a te od kontekstów, w jakich porusza się pytający), od przeświadczenia rozmówcy o tym, co jest, a co nie jest 
o której piszę, widoczna jest także wyraźnie w zestawach tematów poruszanych podczas cyklicznych warsztatów Polskiego Towarzystwa Historii Mówionej - tematy obejmują gównie zagadnienia etyczne i warsztatowe związane z prowadzeniem rozmów ze „świadkami historii”" Wreszcie znajduje odzwierciedlenie w publikowanych tekstach, w tym na łamach najważniejszego periodyku polskiej oral history, „Wrocławskiego Rocznika Historii Mówionej”38.

Podkreślanie interakcyjnego wymiaru historii mówionej, przywiązywanie szczególnej wagi do faktu (często międzygeneracyjnego) spotkania dwóch osób nie jest bynajmniej lokalną specyfiką i bez wątpienia stanowi istotny rys oral history jako takiej. Wydaje się jednak, że dla polskiego środowiska oral history ten aspekt staje się jednym z fundamentów własnej (sub)dyscyplinarnej tożsamości. Dzieje się tak głównie dlatego, że problem interakcji podczas rozmowy - wywiad jako taki - jest „najmniejszym wspólnym mianownikiem” dla przedstawicieli różnych dyscyplin spotykających się na wspólnym gruncie oral history. Chociaż podejście takie daje szansę na wydzielenie w obrębie nauki własnego, osobnego pola, to zarazem ogranicza zakres tej niezależności do minimum. Pociąga za sobą bowiem konieczność rezygnacji z ambicji „tłumaczenia świata” (w tym rekonstrukcji przeszłości) i sprowadza historię mówioną do roli techniki dokumentacyjnej, pozostającej do dyspozycji innych dziedzin wiedzy.

istotne, od jego zasobów interpretacyjnych, od kontekstu (raczej od wielu kontekstów, w jakich się porusza). Spotkanie jest dynamiczną interakcją", P. Filipkowski, Historia mówiona i wojna, [w:] Wojna. Doświadczenie i zapis. Nowe źródta, problemy, metody badawcze, red. S. Buryła, P. Rodak, Kraków 2006, s. 14.

37 M. Jarząbek, K. Żłobecka, Sprawozdanie ze Zjazdów Polskiego Towarzystwa Historii Mówionej w 2016 i 2017 r., „Wrocławski Rocznik Historii Mówionej”, R. 7 (2017), s. 465-468; http://pthm.pl/wp-content/uploads/2018/o4/Program-Warsztatów-Polskiego-Towarzystwa-Historii-Mówionej-w-Lublinie-12-13-V-2018.pdf (dostęp: 5 VII 2018 r.).

38 Zob. np.: M. Jarząbek, It is good to ask good questions - posing questions in oral history interview as a theoretical problem, „Wrocławski Rocznik Historii Mówionej”, R. 6 (2016), s. 21-32; J. Gałęziowski, J. Urbanek, „Etyczny zwrot” w polskiej historii mówionej, „Wrocławski Rocznik Historii Mówionej”, R. 7 (2017), s. 7-34; L. Kościelniak, E. Moroń, Historia migana - między narracja a przektadem. Uwagi metodologiczne do zbierania i opracowywania relacji osób niestyszacych, „Wrocławski Rocznik Historii Mówionej”, R. 7 (2017), s. 35-67. W tym kontekście zob. też głos Marcina Jarząbka w przytaczanej wyżej dyskusji na temat kondycji historii mówionej w Polsce, zorganizowanej podczas konferencji „Oral History in Central-Eastern Europe": P. Filipkowski [et al.], Historia mówiona w Polsce..., s. 304-308. 
Nie znaczy to jednocześnie, że polscy rzecznicy oral history gremialnie porzucili cele poznawcze na rzecz szlifowania warsztatu. Wręcz przeciwnie - świadomi eksplanacyjnej wartości swojej dziedziny - podejmują, nieraz bardzo udane, próby opisu, a nawet teoretyzowania na temat współczesnej lub przeszłej rzeczywistości. Warto jednak podkreślić, że - w odróżnieniu od zachodniego pierwowzoru - wybrali w zasadzie tylko jedną ścieżkę dostępu do opisywanego świata. W skrócie rzecz ujmując: skupili się na „tu i teraz", na samej opowieści, a nie jej przedmiotowych odniesieniach w przeszłości. Należący do tego grona badacze ${ }^{39} \mathrm{w}$ zdecydowanej większości pozostają (bo to przecież dziejąca się, "gorąca” historia) pod wpływem narratywistycznego przełomu w światowej oral history, który dokonał się w końcu lat 70. i w latach 8o. za sprawą z jednej strony metody biograficznej Fritza Schützego, z drugiej - prac włoskich badaczy, na czele z Alessandro Portellim i Luisą Passerini.

U tej stawiającej na interdyscyplinarność grupy ${ }^{40}$ naukowej fascynacji nie wzbudziły struktury z przeszłości odbijające się w biografiach (jaku Thompsona czy Daniela Bertaux) ani tym bardziej rekonstrukcje sekwencji pojedynczych zdarzeń (jak u pierwszych polskich praktyków „źródła wywołanego”). W centrum zainteresowania umieścili narrację. W klimacie postmodernistycznych wahań i odkrycia pamięci przez humanistykę na idola ich naukowej młodości nie nadawał się pochodzący z innej epoki (i reprezentujący inną episteme) Paul Thompson. Znacznie lepiej pasował do tej roli Alessandro Portelli ${ }^{41}$. Dla niejednego badacza odkrywającego historię mówioną na przełomie wieków i szukającego właściwej sobie ścieżki jego deklaracja, że „pierwszym

39 Omawiane tu podejście reprezentują np.: Marta Kurkowska-Budzan, Piotr Filipkowski, Wiktoria Kudela-Świątek i Anna Wylegała. Zob. M. Kurkowska-Budzan, Antykomunistyczne podziemie zbrojne na Białostocczyźnie. Analiza wspótczesnej symbolizacji przeszłości, Kraków 2009; P. Filipkowski, Historia mówiona $i$ wojna. Doświadczenie obozu koncentracyjnego w perspektywie narracji biograficznych, Wrocław 2010; W. Kudela-Świątek, Odpamiętane. O historii mówionej na przykładzie narracji kazachstańskich Polaków o represjach na tle narodowościowym i religijnym, Kraków 2013; A. Wylegała, Przesiedlenia a pamięć. Studium (nie)pamięci społecznej na przykładzie ukraińskiej Galicji i polskich „ziem odzyskanych”, Toruń 2014.

40 Dobrochna Kałwa określi tę grupę mianem „trzeciego pokolenia” oral history w Polsce, zob.: D. Kałwa, Historia mówiona w polskich badaniach dziejów najnowszych..., s. 173.

41 O podejściu do historii mówionej włoskich badaczy (m.in. A. Portellego i L. Passerini), zob. A. Stolarz, Dzielenie się pamięcią..., s. 188-198. 
elementem, który decyduje o odmienności historii mówionej, jest to, że

mówi nam mniej o wydarzeniach jako takich niż o ich znaczeniu"42, stawały się atrakcyjnym drogowskazem. Wartym uwagi także dlatego, że współbrzmiał z ich własnymi dylematami dotyczącymi powiązań „słów i rzeczy”.

Na swój sposób badacze ci, dokonując wyboru takiej optyki w swoim pojmowaniu tego, co przeszłe, starali się właśnie umknąć przed ujęciami historii spetryfikowanymi tradycją badań historycznych. Taką rolę niewątpliwie odgrywało zainteresowanie się pamięcią zbiorową i kariera samego pojęcia pamięci (wykraczającego zresztą daleko poza dyskurs akademicki) ${ }^{43}$.

Skupienie uwagi na pamięci i opowieści wzięło się chyba przede wszystkim z faktu, że badania te niosły ze sobą metodologiczną atrakcyjność i teoretyczne wyrafinowanie właściwe naukom społecznym. Badacze dostawali do rąk pęki interpretacyjnych kluczy (czy skrzynki z narzędziami) oferowane przez poszczególne nauki, które legitymowały się długą tradycją pracy ze słowem mówionym. Mam tu na myśli przede wszystkim socjologię, ale także antropologię czy językoznawstwo. Ich dojrzałe metodologiczne zaplecze decydowało również o dystansowaniu w tym względzie historiografii, która w tej „rozgrywce” o historię mówioną, jak pisałem wyżej, nie miała własnej oferty i nie kwapiła się, by ją sformułować ${ }^{44}$.

I to właśnie narracja jest tym miejscem, w którym polska historia mówiona szuka kontaktu z historią - jej rekonstrukcjami oraz interpretacjami.

42 A. Portelli, The pecularities of oral history, „History Workshop”, 1981, nr 12, s. 99, 100; tłum. częściowo za: M. Kurkowska-Budzan, Bajka o Kopciuszku - oral history, [w:] eadem, Historia zwyktych ludzi..., s. 182-183.

43 Dla samych naukowców (w tym w szczególności historyków) sfera pamięci stanowiła rodzaj bezpiecznego azylu, w którym można było uprawiać swoiście pojętą przeciw-historię, w takim sensie, jaki pamięci nadaje np. Frank Ankersmit: „«Pamięć» reprezentuje wszystko, co zostało wyparte, pominięte bądź stłumione w przeszłości człowieka, i dlatego z samej swej natury nie może zdobyć miejsca w sferze publicznej, sferze tego, co powszechnie znane i uznane - i co zawsze było właściwą domeną «historii» w tradycyjnym sensie", F.R. Ankersmit, Postmodernistyczna „prywatyzacja” przeszłości, [w:] idem, Narracja, reprezentacja, doświadczenie: studia z teorii historiografii, Kraków 2004, s. 373.

44 Jak przekonywała Marta Kurkowska-Budzan, wykorzystanie instrumentarium nauk społecznych i humanistycznych umożliwiło zadawanie nowatorskich pytań i „poszukiwania na nie odpowiedzi w jasno określonych, uprawomocnionych akademicką tradycją, bądź mających naukowy, czyli przynajmniej systematyczny charakter, ramach teoretycznych", P. Filipkowski [et al.], Historia mówiona w Polsce..., s. 301. 
Albo może inaczej: narracja jest dla historii mówionej wrotami do przeszłości. To w ten sposób, przy użyciu swojego najbardziej wyrafinowanego „uzbrojenia”, próbuje dokonać desantu na teren badań historycznych. Są to jak dotąd próby co najwyżej nieśmiałe, raczej pozostające w sferze deklaracji - lecz nawet jako takie warte odnotowania. Trend ten ma swoje dwie odsłony - zgodne z dwoma głównymi nurtami historii mówionej rozpoznanymi niegdyś przez Michaela Frischa. I tak w duchu more-history mieszczą się ponawiane od lat (z niewielkim praktycznym skutkiem) zachęty do odnajdywania w historii mówionej sfery mentalności czy życia codziennego. Z drugiej strony, pojawia się nadzieja na stworzenie na podstawie relacji ustnych rodzaju przeciw-historii (anti-history), stawiającej opór dominującym w polskiej historiografii obrazom przeszłości. Najnowszymi i na pewno najbardziej dojrzałymi przykładami tej ostatniej tendencji są dwa niedawne artykuły Tomasza Rakowskiego i Piotra Filipkowskiego. Rozwijaną w nich koncepcję „wiedzy pewnej” przenika właśnie wiara w tkwiący w narracjach „świadków historii” potencjał zaproponowania odmiennych obrazów przeszłości. Chodzi, jak stwierdza w pewnym momencie Filipkowski, „o dostrzeżenie w historii mówionej potencjału na opowiedzenie innej historii, na inną historyczną logikę"45. Z kolei według Rakowskiego:

odsłonięcie historii budowanych na materiale mówionym i nieformalnym może być podstawą rekonstrukcji nie tylko świata antropologicznego (tego, co ludzie „myślą”, co „gadają”), ale może być też bazą do rekonstrukcji powiązanych ze sobą wydarzeń umożliwiających odsłonięcie „innych” historii, niedostępnych dotąd dominującym rozpoznaniom ${ }^{46}$.

Istotę opisywanego tu kierunku działania najlepiej oddaje inny fragment przywoływanego wyżej tekstu Piotra Filipkowskiego. Bazując na wspomnieniach konkretnej osoby (podaje przykład jednej z rozmów Rakowskiego z Elżbietą Szewczyk, z którą ten ostatni spotykał się wielokrotnie podczas swych badań na południowym Mazowszu), przekonuje, w jaki sposób historia mówiona może zapewnić inne (od tych opartych na materiałach aktowych) ramy dla rekonstrukcji przeszłości:

45 P. Filipkowski, Historia mówiona jako historia faktyczna..., s. 106.

46 T. Rakowski, Historia mówiona i źródła etnograficzne jako „wiedza pewna”. Przypadek potransformacyjnej historii Torgutów w zachodniej Mongolii oraz historii wsi Broniów w centralnej Polsce, „Rocznik Antropologii Historii”, R. 5 (2015), s. 65. 
[...] to nie jest przecież tak świetnie nam znane z historycznych sporów przeciw-

stawianie jednych faktów - innym, lansowanie własnych faktów przeciwko faktom lansowanym przez innych. Tu fakty czy informacje „bazowe” - by sięgnąć do kategorii z metodologii historii Jerzego Topolskiego - między narracją dużą, oficjalną, i małą prywatną, są w pełni zgodne. [...] Inna jest „tylko” ich interpretacja, inne są reguły ich wiązania, inne związki przyczynowo-skutkowe. Inne - choć niekoniecznie zupełnie sprzeczne i całkowicie się nawzajem wykluczające. Narracja mała rozszerza tu jakby tę dużą i niuansuje ją. Tak dalece jednak, że proponuje alternatywną logikę historyczną zbudowaną na tych samych faktach ${ }^{47}$.

Fragment ten jest w moim odczuciu reprezentatywny dla zadomowionego we współczesnej polskiej historii mówionej stosunku do badań nad przeszłością - wiary w możliwość dotarcia do przeszłości za pomocą mniejszych lub większych całości narracyjnych.

Manewr jednak nie jest tak prosty, jak z pozoru się wydaje, bo pomiędzy obszarem badawczym oralisty ${ }^{48}$ i historyka występuje niemożliwa do przezwyciężenia sprzeczność. Polega ona na tym, że oral history w inny sposób, niż to się dzieje w historiografii, ujmuje relacje słów i świata, żeby posłużyć się tu określeniem Jerzego Topolskiego ${ }^{49}$. Jeżeli spojrzymy na powyższy fragment tekstu Piotra Filipkowskiego z takiego punktu widzenia, to dostrzeżemy, że autor nie stosuje żadnej przezroczystej ani neutralnej epistemologicznie matrycy. Przeciwnie, ustanawia szczególnego typu relację na linii słowa-rzeczy. Nie jest ona przypadkowa - pozostaje w zgodzie $\mathrm{z}$ poznawczymi fundamentami historii mówionej (zaczerpniętymi z kolei z nauk społecznych i literaturoznawstwa).

Zasadniczo mamy w niej do czynienia z układem dwuelementowym. Składnikiem pierwszym i jednocześnie punktem odniesienia jest przeszłość sama w sobie - res gestae. Historia mówiona, koncentrując się na narracji i pamięci, ontologię świata przedstawianego na ogół bierze w nawias. Sytuacja jednak w oczywisty sposób się zmienia, kiedy rzuca wyzwanie historiografii.

47 P. Filipkowski, Historia mówiona jako historia faktyczna...

48 Nazwa „oralista” na określenie specjalistów oral history, zaproponowana przez Dobrochnę Kałwę, staje się coraz bardziej popularna - pojawia się zarówno w dyskusjach, jak i w publikowanych tekstach. Zob. np.: J. Gałęziowski, J. Urbanek, „Etyczny zwrot" w polskiej historii mówionej...

49 J. Topolski, Jak się pisze i rozumie historię. Tajemnice narracji historycznej, Warszawa 1998 (wyd. 2), s. 379. 
Wtedy uznanie tej ontologii oraz odniesienie do niej stają się warunkami koniecznymi (ale - jak wykażę - niewystarczającymi) całego przedsięwzięcia. Drugim elementem jest sama narracja. Ustanowione zatem zostaje odniesienie: świat badany (ontologia) - przedstawienie (które, jak pokażę później, łączy w sobie epistemologię i estetykę). Takie ustawienie relacji ma konkretne konsekwencje. Warto zauważyć, że wówczas to narracja jest miejscem kreowania obrazów przeszłości - nie jakichś drobnych wycinków, ale względnie koherentnych całości („Narracja mała rozszerza tu jakby tę dużą i niuansuje ją. Tak dalece jednak, że proponuje alternatywną logikę historyczną zbudowaną na tych samych faktach"50). A twórcą tych obrazów staje się rozmówca/świadek historii. To on ma za zadanie proponować alternatywne, odświeżające interpretacje przeszłości, które rzucałyby wyzwanie jej dominującym w historiografii przedstawieniom. Tym samym odgrywa rolę autorytetu - bo w swojej opowieści wiąże miniony świat w (alternatywną) całość.

\section{Powrócić do źródeł}

Nie mam wątpliwości, że zdefiniowany powyżej tryb działania może przynieść ciekawe rezultaty. W szczególności może zaowocować nieszablonowymi interpretacjami przeszłości, a ściślej: jej nowymi reprezentacjami. Z perspektywy profesjonalnego historyka ma jednak jedną, ale za to bardzo poważną wadę - jest zewnętrzny wobec sposobu odnoszenia się do przeszłej rzeczywistości właściwego historiografii.

Źródło problemu dobrze oddała swego czasu Marta Kurkowska-Budzan, pisząc o specyfice historii mówionej:

Rozmówcy, dzieląc się swoimi wspomnieniami, a przy tym opiniami, nie relacjonują bezpośrednio wydarzeń, nie odtwarzają ich, lecz wyrażają przez nie: co teraz myślą, że wiedzą; co teraz myślą, że wtedy widzieli; co teraz myślą, że wtedy przeżyli. Sytuacja wywiadu jest niepowtarzalnym wydarzeniem, w którym przy współudziale badacza [...] powstaje opowieść o życiu, za którą stoi a-czasowe w pewnym sensie doświadczenie narratora, będące immanentną częścią jego jaźni ${ }^{51}$.

$50 \quad$ Zob. przyp. 47

51 M. Kurkowska-Budzan, Ile cukru w cukrze..., s. 123. 
W tym kontekście, w innej publikacji dodawała: „[Oral history] odnosi się wszak do czasowo niemierzalnego doświadczenia, a nie wydarzeń w czasie", by na koniec zadać niebłahe z punktu widzenia historyka pytanie: „Skoro wymiar czasu jest tu tak mało ważny, to czy jest to jeszcze historia?" 52 .

Powyższe słowa zinterpretować można jako kwestionujące wiarygodność historii mówionej. Chociaż takie odczytanie jest uprawnione, to jestem zdania, że przytoczona obserwacja operuje także na głębszym poziomie. Autorka wyostrza w niej to, co stanowi źródło - najczęściej zresztą tylko intuicyjnie odczuwanej - dezorientacji każdego niemal historyka stykającego się z historią mówioną. A niepewność ta wynika wprost ze wspomnianego już wcześniej odmiennego w przypadku historiografii sposobu łączenia się „słów” i „świata”.

Jak przekonująco wskazuje narratywistyczna teoria historii, w szczególności w pracach Franka Ankersmita i Jerzego Topolskiego, relacja przedmiotu opisu z jego historiograficznym przedstawieniem jest trójpoziomowa. Po pierwsze, historyk zakłada istnienie rzeczywistości przeszłej. Drugim poziomem jest faza „odnoszenia się” (Ankersmit) lub nawiązywania „punktowego kontaktu” (Topolski) z przeszłością, osiąganego na drodze empirycznych badań, których skutkiem są pojedyncze zdania prawdziwe. W trzeciej fazie, wokół tych zdań, lub w oparciu o nie, historyk tworzy swój obraz przeszłości ucieleśniony w narracji (Ankersmit napisze o historycznym przedstawieniu/ reprezentacji, odwołując się do metaforyki malarskiej). Pierwszy szczebel ma charakter ontologiczny, drugi jest tożsamy z epistemologią, zaś finalny, obejmujący tworzenie narracji - to poziom estetyki ${ }^{53}$.

Sądzę, że takie zdefiniowanie relacji między pracą historyka a opisywaną przez niego rzeczywistością wyraźnie zakreśla linię demarkacyjną między „terytoriami” historiografii i historii mówionej. Różnica między rozpoznanym w tekście Piotra Filipkowskiego dwustopniowym modelem

52 Eadem, Antykomunistyczne podziemie zbrojne..., s. 91-92.

53 F.R. Ankersmit, Zwrot lingwistyczny: teoria literatury a teoria historii, [w:] idem, Narracja, reprezentacja, doświadczenie..., s. 107; J. Topolski, Jak się pisze i rozumie historię..., s. 77-78, 379-388. Por. też krytykę stanowiska Topolskiego, zakładającego „punktowy kontakt” z rzeczywistością przeszłą, sformułowaną przez Wojciecha Wrzoska, W. Wrzosek, Źródto historyczne jako alibi realistyczne historyka, [w:] Historyk wobec źródet. Historiografia klasyczna i nowe propozycje metodologiczne, red. J. Kolbuszewska, R. Stobiecki, Łódź 2010, s. 22-38. 
wyjaśniania a zaprezentowanym wyżej schematem trójstopniowym nie jest marginalna. To nie żadna szczelina, którą można zasypać lub zamaskować zapewnieniami o interdyscyplinarności, lecz dzielący dyscypliny kanion. A to dlatego, że konsekwencją przejścia z dwustopniowego na trójstopniowy model odniesienia staje się reorientacja postępowania badawczego. A konkretnie: decyzja taka pociąga za sobą inną dystrybucję odpowiedzialności.

Jak zaznaczałem, historia mówiona szuka kontaktu z przeszłością poprzez narrację. W takiej sytuacji twórcą obrazu rzeczywistości minionej staje się sam rozmówca/świadek historii - to on ma wiązać elementy przeszłego świata, a wiązanie odbywa się „tu i teraz”. Gdyby popatrzeć na opisany manewr z perspektywy historyka, oznacza on, ni mniej, ni więcej, tylko połączenie etapu badania (ustalania faktów) z tworzeniem przedstawienia, czyli krokiem o charakterze już estetycznym.

Historyk natomiast te dwa etapy od siebie oddziela. Mimo że przesunięcie wydaje się nieznaczne i z reguły pozostaje nieuświadomione, ma fundamentalne znaczenie. W jego efekcie historyk musi przejąć odpowiedzialność za narrację - on jest jej twórcą. Zaczyna od ustalania tego, co Jerzy Topolski nazwał indywidualnymi faktami historycznymi, by potem na drodze twórczej, literackiej już w zasadzie pracy, wiązać efekty swojego badania w jednolitą, przekonującą, prawdziwą i atrakcyjną dla odbiorców reprezentację przeszłości. Obrazowo tę sytuację ujął Topolski, pisząc:

Ustalenia indywidualnych faktów historycznych są swego rodzaju punktami zaczepienia do zorganizowania wokół nich narracji. Nie są, odwołując się w dalszym ciągu do metafor, cegiełkami, z których można wznosić różne budowle (tzn. tworzyć różne narracje), lecz właśnie takimi punktami zaczepienia dla narracji, która nie tylko z nich, czy nie tyle z nich powstaje. Można by narrację przyrównać raczej do jakiejś tkaniny rozwieszonej przy wykorzystaniu owych nie podlegających w zasadzie dyskusji ustaleń dotyczących pojedynczych faktów historycznych. Tkanina ta może być różna i różnie tkana, a nawet może być (jak to często w narracji historycznej bywa) utkana z elementów fikcyjnych, lecz nie może (czy nie powinna) być rozwieszona na fikcyjnych punktach zaczepienia. Narracja historyczna przekroczyłaby wówczas granicę dzielącą ją z literacką fikcją ${ }^{54}$.

54 J. Topolski, Jak się pisze i rozumie historię..., s. 347. 
Resumując powyższy wątek - podstawowe epistemologiczne założenie historiografii jest takie, że to historyk tworzy obrazy przeszłości, nie czyni zaś tego źródło - chociażby nie wiem jak bardzo było perswazyjne. Oddanie obowiązku/przywileju spajania elementów przeszłego świata rozmówcy/świadkowi historii przeczy logice poznania historycznego. Jak starałem się wykazać, elementem różnicującym historiografię i historię mówioną jest wyraźne (choć często domyślne i nieuświadomione) rozdzielenie epistemologii (badanie) i estetyki (przedstawienie).

Wniosek z powyższego byłby zatem taki, że aby projekt napisania jakiejkolwiek „innej historii” za pomocą historii mówionej był do pomyślenia - potrzebne jest w pierwszej kolejności zejście piętro niżej: z efektu (narracji) na środek do niego prowadzący, czyli na badanie - tak, jak w przytoczonych wyżej modelach poznania historycznego definiowali je Ankersmit i Topolski.

Ontologicznym tłem operacji jest uznanie, za Haydenem White’em, że zdarzenia rzeczywiste nie mają charakteru narracyjnego, „nie jawią nam się w kształcie opowieści" ${ }^{55}$. Przeszłość sama w sobie jest za to chaotyczna i na swój sposób niesforna - jej pojęcie i zrozumienie wymaga uporządkowania. To z kolei umożliwia narracja - zapewnia wrażenie opanowania różnorodności minionego świata. Stąd, jak przekonuje White, mamy tendencję, by przyjmować takie „rozumienie rzeczywistości, w ramach którego to, co «prawdziwe», utożsamiane bywa $\mathrm{z}$ «rzeczywistym» tylko jeśli uda się wykazać, że ma charakter narracyjny" ${ }^{\text {"56 }}$. Jak się wydaje, przytoczona obserwacja wyjątkowo trafnie opisuje sposób traktowania wywiadów właściwy historii mówionej. Zbierając i wykorzystując relacje, jako badacze już domyślnie przyjmujemy założenie fabularyzacji opowieści, a dokładniej jej wersję minimalną: wymóg czasowego zamknięcia. Występuje on w dwóch podstawowych wariantach: 1) wydarzeniowym - kiedy rozmówca staje się „świadkiem Historii” - relacjonuje wielkoskalowe i znaczące z perspektywy historiografii/polityki pamięci wydarzenie (np. Powstanie Warszawskie); 2) biograficznym - w tym przypadku oczekujemy „kompletnej” opowieści o życiu (w tym sensie idea przeprowadzania wywiadów z najstarszymi generacjami i rozpoczynania rozmowy od najwcześniejszych wspomnień miałaby właśnie uzasadnienie fabularne [estetyczne], a nie epistemologiczne).

\footnotetext{
${ }_{5} \mathrm{H}$. White, Znaczenie narracyjności dla przedstawiania rzeczywistości, [w:] idem, Poetyka pisarstwa historycznego, Kraków 2010, s. 140.

56 Ibidem, s. 143.
} 
W szkicowanym tu zamierzeniu chodzi przede wszystkim o odmienny typ „faktyczności” niż ten oparty na tradycji oral history. W tym ujęciu to nie, jak chce Piotr Filipkowski, „fakty czy informacje «bazowe» między narracją [...] oficjalną, i [...] prywatną mają być «w pełni zgodne»" ${ }^{\text {, }}$, a miejscem zróżnicowania jest ich narracyjna interpretacja przez rozmówcę. Logika poznania i warsztatu historycznego podpowiadają operację dokładnie odwrotną - szukanie i wyławianie pojedynczych drobnych informacji z potoku narracji. Kryje się za tym postulat „rozbicia narracyjności” relacji ustnej - docenianie tego, co jest przedmiotem „klejenia”, z pomniejszeniem roli samego narracyjnego wiązania. W ten sposób punktami odniesienia stają się stany pośrednie między rzeczywistością przeszłą a reprezentacją/ narracją: stwierdzenia o faktach Ankersmita, zdania kronikarskie White'a, czy stwierdzenia o indywidualnych faktach/zdania bazowe Topolskiego ${ }^{58}$.

Daleki jestem przy tym od absolutyzowania tych elementów czy traktowania ich jako wiernie odbijających rzeczywistość. Z przytoczonych stanowisk wskazanych teoretyków zapożyczam przede wszystkim właściwy im kierunek myślenia. Zatem nie sugeruję ujęcia zero-jedynkowego, dokładnej transmisji przeszłości poprzez pojedyncze zdania o faktach. Sformułowana propozycja nie jest wyrazem ani tym bardziej pochwałą „spontanicznego realizmu" ${ }^{59}$. Nie chodzi tu jednak o definitywne teoretyczne rozstrzygnięcia, lecz raczej uzyskanie empirycznie użytecznego sposobu postępowania. Jego istotą jest motywowany właśnie potrzebami historyków-praktyków „ruch do rzeczywistości”. Wehikuły tej podróży (która nota bene jest skazana tylko na zbliżanie się do celu, a nie na jego osiągnięcie) stanowią właśnie pojedyncze, drobne „bity informacji”.

W całej proponowanej tu operacji kluczowy jest, uzyskany dzięki skupieniu uwagi na najmniejszej porcji informacji, modus operandi. Zgodnie z nim celem nie jest wydobywanie ze słów rozmówców konkurencyjnych narracji, ale raczej ich podstawy, a może nawet lepiej - punktu wyjścia. Kontakt z rozmówcą, sytuacja wywiadu, a wreszcie analiza zgromadzonego materiału jest tu widziana jako okazja do chwytania migotliwych, nietrwałych refleksów

57 Zob.: przyp. 46.

58 Zdanie bazowe (i stojąca za nim informacja bazowa) to według Topolskiego zdania o „bardzo niskim stopniu nasycenia interpretacją”, takie, które nie są przedmiotem sporu wśród historyków, J. Topolski, Jak się pisze i rozumie historię..., s. 382-383. Por.: W. Wrzosek, Źródto historyczne jako alibi... 
przeszłej rzeczywistości, nadających się do kierowania narracji tworzonej przez historyka na niekonwencjonalne tory, ale w pierwszym kroku - do wpływu na sam proces badawczy. Być może warto założyć, że w spotkaniu dwojga ludzi: badacza i jego rozmówcy kryje się nie tylko opowieść konkurencyjna wobec narracji odgórnych, ale też możliwość odkrycia wymykających się schematom odniesień do małych fragmentów przeszłej rzeczywistości; zapewne nielicznych okruchów przeszłości - które odgrywają rolę iskier - „zapalników”, wykazujących zdolność do inicjowania alternatywnych rozpoznań przeszłości.

Nie są one ani ostateczne, ani „pewne” nie tylko w sensie odbicia świata badanego, lecz także w relacji z innymi zdaniami oraz tworzoną finalnie narracją historyka. Oznacza to, że nie muszą odgrywać „kotwic” dla narracji - pewnych, niepodlegających dyskusji i interpretacji zdań (czyli zdań/ informacji bazowych Topolskiego), ale mają stanowić dogodny punkt oparcia dla ich wyłonienia się. Takie minimalne porcje informacji odgrywałyby zatem rolę analogiczną do „pojęć uczulających” znanych z teorii ugruntowanej ${ }^{60}$. Gdyby posłużyć się użytą przez Topolskiego metaforą narracji jako tkaniny, to jednostkowe informacje zaczerpnięte $\mathrm{z}$ wywiadu, w wersji minimum, nie tyle stawałyby się „punktami zaczepienia”, ile sugerowałyby miejsca, w których takie „zaczepy” można by rozmieścić.

Oczywiście omówiona tu zasada może dotyczyć każdego innego źródła historycznego, każdego przekazu dotyczącego przeszłości. Wydaje się jednak, że relacje ustne, a szczególnie dialogiczna sytuacja wywiadu, maksymalizują opisaną możliwość. Dzieje się tak z powodu dwóch właściwości historii mówionej, dobrze znanych każdemu, kto miał okazję przeprowadzać wywiad lub korzystać z zarejestrowanego materiału.

Po pierwsze, rejestracja relacji jest jedyną sytuacją, w której historyk może wpływać na swoje „źródło”. Wiąże się to, jak wiadomo, ze sporym ryzykiem i ma liczne negatywne konsekwencje, na czele z możliwością znacznego zniekształcenia przekazu. Warto jednak podjąć próbę ujrzenia w tym, co wydaje się obciążające, impulsu pozytywnego. Bo unikalna sytuacja wywiadu niesie

60 „Pojęcia uczulające” w teorii ugruntowanej „wskazują kierunek, w którym trzeba patrzeć" (w odróżnieniu od pojęć jednoznacznych/rozstrzygających, które decydują, co obserwować), H. Blumer, Interakcjonizm symboliczny. Perspektywa $i$ metoda, Kraków 2007, s. 115; za: M. Kurkowska-Budzan, Antykomunistyczne podziemie zbrojne..., s. 23. Por.: K.T. Konecki, Studia z metodologii badań jakościowych. Teoria ugruntowana, Warszawa 2000. 
nie tylko zagrożenia wypaczeniem, a może i przekłamaniem, lecz także rozmaite korzyści: pozwala na wybór tematu rozmowy, samego rozmówcy, szczegółowych zagadnień poruszanych w trakcie rozmowy i wreszcie na modyfikowanie pytań na bieżąco. W rezultacie badacz przeszłości, dzięki własnej naukowej kreatywności oraz interakcji ze swoim rozmówcą, jest w stanie postawić nowe, nieszablonowe pytania. Odmienne nie znaczy, że stojące w kontrze do istniejących narracji, ale wychodzące z całkowicie innej logiki, np. w punkcie wyjścia ignorujące zupełnie tzw. wielką historię.

Po drugie, nieprzewidywalność interakcji sprzyja „wyławianiu” alternatywnych faktów i nieschematycznych informacji. Niejednemu badaczowi spontaniczność - nieodłączna towarzyszka międzyludzkich spotkań (choćby nie wiem jak sformalizowanych) - spędza sen z powiek. Nie dość, że często nie wie on do końca, czego może się spodziewać podczas wywiadu, to jeszcze $\mathrm{w}$ jego efekcie dostaje materiał nieuporządkowany, pełen dygresji, informacji niepełnych i przemilczeń, a chronologia takiej opowieści jest w najlepszym razie nieścisła. Taki ogląd jest w pełni uprawniony (podobnie jak wynikające z niego zniechęcenie do „źródła wywołanego") pod warunkiem, że traktujemy nagrany dialog jako narracyjną całość (lub zbiór „scen z życia”). Sprawa przedstawia się jednak inaczej, jeśli popatrzymy na nagrany materiał jak na zestaw potencjalnie ciekawych zdań i informacji. Wtedy nieprzewidywalność, chaotyczność wywiadu staje się bardziej zaletą niż wadą. Umożliwia bowiem wybicie się niezaplanowanego szczegółu, wyłowienie takich elementów, które przez zamknięte narracyjne struktury albo język oficjalny są zwykle tłumione.

Oczywiście wydobywanie na światło dzienne i korzystanie ze wszystkich tych drobin, pojedynczych zdań i mimochodem rzuconych słów, które mogą okazać się potencjalnie wartościowe, wymaga wyjątkowej spostrzegawczości. Ale właśnie do tego swoiście pojętego „zbieractwa” doskonale nadaje się, lub przynajmniej powinien nadawać się, historyk, z charakteryzującymi jego profesjonalne przygotowanie wyczuleniem na szczegół, krytycyzmem, a też i nieufnością do śladów res gestae.

Paradoksalnie wydaje się, że jeśli chodzi o wykorzystanie relacji ustnych w badaniach przeszłości, historycy mają więcej do zaoferowania, niż ich krytycy gotowi byliby przyznać, a możliwe, że także więcej, niż sami się spodziewają. Sformułowanie takiej oferty wymaga jednak nie odniesienia się do praktyki wykorzystania „źródła wywołanego” w badaniach historycznych, ale do autorefleksyjnego spojrzenia na podstawy własnej dyscyplinarnej odrębności. Chodziłoby o przyjęcie postawy, którą Ewa Domańska określiła mianem „atawizmu pozytywistycznego". Jak pisała w Historii egzystencjalnej: 
[...] być może pozytywistycznie prowadzone badania warsztatowe ze swoją dbałoś-

cią o szczegóły i specyfikę rzemiosła ${ }^{61}[. .$.$] , wraz z otwarciem się na nowe tenden-$ cje panujące w humanistyce, ale bez instrumentalnego wykorzystania gotowych narzędzi, które wypływające z nich teorie podsuwają, zagwarantują dyscyplinie status otwartej dynamicznej struktury i mocnego „podmiotu” humanistyki [...] Pomysł jest zatem taki: z jednej strony otwarcie na to, co dzieje się w humanistyce, na „nowinki” i na odmienne podejścia do przeszłości, a z drugiej zamknięcie w sensie zachowania i ochrony podstaw dyscypliny (krytyka źródła, metodyka pracy archiwalnej) oraz tradycyjnego podejścia do pracy badawczej, które cechuje sumienność, umiarkowanie, krytyczność, dogłębność, cierpliwość i rzetelność ${ }^{62}$.

W przypadku pracy z relacjami ustnymi historyk jest właściwym człowiekiem na właściwym miejscu, nie tylko z racji swej dociekliwości, ale także dlatego, że niejako automatycznie (to znowu część jego warsztatu) powinien potrafić dokonane odkrycie skontekstualizować. Czyli powiązać swoje znalezisko z korpusem dostępnych źródeł, tak by stworzyć atrakcyjną i wartościową poznawczo interpretację przeszłości. Przełamywanie prymatu archiwum w badaniach historycznych może wszak polegać także na tym, że dzięki informacjom wydobytym $\mathrm{z}$ tych innych źródeł badanie konwencjonalnych źródeł zostanie inaczej ukierunkowane, a pytania badawcze dotkną innych obszarów.

Naiwnością byłoby przy tym zakładać, że zdolność do stworzenia jakichkolwiek innych interpretacji ogranicza się wyłącznie do odnalezienia i interpretacji śladu przeszłości, czy do sposobu odczytania jego konkretnego typu (w tym wypadku: relacji ustnej). To tylko i aż punkt wyjścia: warunek konieczny, ale nie wystarczający. Wymaga jednak umieszczenia w kontekście. I nie mam tu na myśli w pierwszym rzędzie kontekstu innych materiałów (chociaż one też są ważne, ale na dalszym etapie), tylko kontekst postępowania badawczego. Specyficzny materiał rozpoczynający badanie - wyabstrahowane $\mathrm{z}$ narracji bity informacji - wymagają właściwie przygotowanego

${ }^{61}$ Tu autorka wyraźnie zastrzega, że nie jest jej celem uwzględnianie całej tradycji pozytywistycznego myślenia. Odżegnuje się od „bezkrytycznego odwoływania się do pozytywistycznych dogmatów (na przykład tradycyjnie ujmowanej wiedzy o przeszłości, Prawdy, kultu źródła, które dostarcza prawdziwej wiedzy o przeszłości, fetyszu genezy, idei postępu, telosu, linearnej chronologii i myślenia w kategoriach przyczynowo-skutkowych)", E. Domańska, Historia egzystencjalna. Krytyczne studium narratywizmu i humanistyki zaangażowanej, Warszawa 2012, s. 168.

62 Ibidem, s. 168, 169. 
"laboratorium”. I w tym miejscu „wrażliwość historyczna” musi sprzęgnąć się z „wrażliwością etnograficzną/antropologiczną". Co to oznacza? Przede wszystkim odrzucenie hierarchicznych, wertykalnych zależności, które historiografia uczyniła jednym ze swych dogmatów. W gruncie rzeczy chodzi zatem o rozbicie narracji nie tylko na poziomie źródła, ale także jako struktury wdrukowanej w myślenie o historii.

Tu szczególnie użyteczny mógłby być zbiór dyrektyw metodologicznych wypracowanych w ramach teorii ugruntowanej, z jej umieszczoną w centrum zasadą prymatu empirii nad teorią i brakiem prekonceptualizacji badań - streszczonych w wezwaniu, by pozwolić teoriom wyłonić się z danych. Z punktu widzenia wykorzystania relacji ustnych w badaniach historycznych najbardziej obiecującą właściwością teorii ugruntowanej wydaje się „kartograficzne” metaforyzowanie badanej rzeczywistości. Zamiast układów pionowych, do których, jak zaznaczałem, polska historia najnowsza jest silnie przywiązana (z państwem czy „władzą” na czele), teoria ugruntowana proponuje czerpanie siły z rozproszenia i wiązania różnych aktorów/aktantów przez badacza. Zamiast dokładania szczebli drabiny czy szeregowania elementów w hierarchicznym układzie, dostajemy zachętę do rysowania mapy i zauważania układów odniesień ${ }^{63}$.

Takie podejście, co nietrudno zauważyć, silnie koresponduje z rozproszonym, nieustrukturyzowanym charakterem informacji przekazywanych podczas wywiadu. A przede wszystkim - pozwala na wyzyskanie nawet najdrobniejszych elementów zawartych w przekazie ustnym i ukierunkowanie za ich pomocą samego procesu badawczego, a w efekcie także tworzonej historiograficznej narracji - być może „jakiejś innej historii”.

Intuicja towarzysząca pionierom historii mówionej (także polskim), jak się wydaje, nie traci i dziś swej aktualności. W rozmowie, w spotkaniu z drugim człowiekiem, w jego wywołanych przy udziale historyka wspomnieniach bez wątpienia tkwi potencjał do (współ)tworzenia odświeżających obrazów przeszłości. Z punktu widzenia polskiej historiografii dziejów najnowszych zaproponowanie zbudowanych na podstawie owej rozmowy rozpoznań na pewno byłoby korzystne.

${ }_{63}$ Zob.: A.E. Clarke, Situational Analysis. Grounded Theory After the Postmodern Turn, London-New Dehli 2005; K.T. Konecki, Studia $z$ metodologii...; M. Kurkowska-Budzan, Antykomunistyczne podziemie zbrojne...; eadem, M. Stasiak, Stadion na peryferiach..., s. 321-350. 
Być może koniecznym choć nieoczekiwanym warunkiem powodzenia pomysłu tak rozumianego włączenia wywiadu/relacji ustnych do badań nad przeszłością jest rezygnacja z podstawowych metafor organizujących ich usus oraz refleksję teoretyczną: historii mówionej oraz świadka historii. Wraz z najnowszym, zyskującym popularność określeniem oralisty, stają się one pojęciami emblematycznymi dla wyodrębniającej się powoli, ale konsekwentnie (sub) dyscypliny badań humanistycznych/społecznych - oral history.

Otwarte pozostaje pytanie o pojęciowe, a więc i konceptualne ujęcie relacji ustnych w ramach historiografii. Podstawowe pojęcia oczywiście istnieją i są stosowane przez historyków. Mam tu na myśli głównie „źródło wywołane" oraz respondenta/informatora. Kłopot w tym, czy, po dekadach postmodernistycznych debat, powrót do tego pojęciowego zestawu ściśle sprzężonego z pozytywistycznymi i modernistycznym ideałami uprawiania nauki jest zasadny i możliwy. Zwłaszcza jeśli chcemy za jego pomocą tworzyć „nową” historię? Czy nie potrzebujemy, jako historycy, nie jako oraliści, refleksji nad słownikiem ${ }^{64}$ odnoszącym się do tego fragmentu naszego warsztatu badawczego? Jego przemyślenie i powstanie można by uznać za oznakę integracji metody z dyscypliną.

${ }^{64}$ W tym kontekście warto przywołać uwagi Ewy Domańskiej dotyczące znaczenia metaforyzowania elementów stojących między przeszłością a badaczem w określaniu naukowej tożsamości jego samego. Domańska zwraca uwagę na epistemologiczne konsekwencje używania czterech pojęć: „źródła historycznego”, „dowodu”, „pozostałości” oraz „śladu” i dowodzi, że świadomie używane mogą służyć identyfikacji warsztatowych założeń historyka, stanowić jego swoiste metodologiczne credo. Zob.: E. Domańska, Nekros. Wprowadzenie do ontologii martwego ciała, Warszawa 2017, s. 127-129. 
Ankersmit F.R., Postmodernistyczna „prywatyzacja” przeszłości, [w:] idem, Narracja, reprezentacja, doświadczenie. Studia z teorii historiografii, red. E. Domańska, Kraków 2004, s. 367-401.

Ankersmit F.R., Zwrot lingwistyczny: teoria literatury a teoria historii, [w:] idem, Narracja, reprezentacja, doświadczenie. Studia z teorii historiografii, red. E. Domańska, Kraków 20o4, s. $71-129$.

Blumer H., Interakcjonizm symboliczny. Perspektywa i metoda, Kraków 2007.

Clarke A.E., Situational Analysis. Grounded Theory After the Postmodern Turn, London-New Dehli 2005.

Domańska E., Historia egzystencjalna. Krytyczne studium narratywizmu i humanistyki zaangażowanej, Warszawa 2012.

Domańska E., Nekros. Wprowadzenie do ontologii martwego ciała, Warszawa 2017.

Eisler J., Marzec 1968. Geneza, przebieg, konsekwencje, Warszawa 1991.

Eisler J., Refleksje nad wykorzystaniem relacji jako źródta w badaniu historii PRL (rozmowy $z$ dysydentami i prominentami), „Polska 1944/45-1989. Studia i materiały”, t. 6 (2004), s. 23-48.

Filipkowski P., Historia mówiona i wojna, [w:] Wojna. Doświadczenie i zapis. Nowe źródta, problemy, metody badawcze, red. S. Buryła, P. Rodak, Kraków 2006.

Filipkowski P., Historia mówiona $i$ wojna. Doświadczenie obozu koncentracyjnego w perspektywie narracji biograficznych, Wrocław 2010.

Filipkowski P., Historia mówiona jako historia faktyczna albo jak „odantropologizować” opowieści o przeszłości?, „Rocznik Antropologii Historii”, R. 5 (2015), s. 91-108.

Filipkowski P., Wylegała A., Kurkowska-Budzan M., Jarząbek M., Historia mówiona w Polsce. Głosy w dyskusji (podczas konferencji „Oral History in Central-Eastern Europe: Current Research Areas, Challenges and Specificity”, Łódź, 17-18 września 2015 r.), „Wrocławski Rocznik Historii Mówionej", R. 5 (2015), s. 293-308.

Frisch M., A Shared Authority: Essays on the Craft and Meaning of Oral History, Albany-New York 1990.

Friszke A., Anatomia buntu. Kuroń, Modzelewski i komandosi, Kraków 2010.

Gałęziowski J., Urbanek J., „Etyczny zwrot” w polskiej historii mówionej, „Wrocławski Rocznik Historii Mówionej", R. 7 (2017), s. 7-34.

Jarosz D., Mieszkanie się należy. Studium z peerelowskich praktyk społecznych, Warszawa 2010.

Jarosz D., Miernik G., „Zhańbiona” wieś Okót: opowieść o buncie, Warszawa-Kielce 2016.

Jarska N., Kobiety z marmuru: robotnice w Polsce w latach 1945-196o, Warszawa 2015.

Jarząbek M., It is good to ask good questions - posing questions in oral history interview as a theoretical problem, „Wrocławski Rocznik Historii Mówionej”, R. 6 (2016), s. 21-32.

Jarząbek M., Żłobecka K., Sprawozdanie ze Zjazdów Polskiego Towarzystwa Historii Mówionej w 2016 i 2017 r., „Wrocławski Rocznik Historii Mówionej”, R. 7 (2017), s. 465-468. 
Kałwa D., Historia mówiona w krajach postkomunistycznych. Rekonesans, „Kultura i Historia”, nr 18 (2010), http://www.kulturaihistoria.umcs.lublin.pl/archives/1887 (dostęp: 4 VII 2018 r.).

Kałwa D., Historia mówiona w polskich badaniach dziejów najnowszych, „Wrocławski Rocznik Historii Mówionej”, R. 7 (2017), s. 163-183.

Kałwa D., Kozetka historyka: oral history w badaniach życia prywatnego, [w:] Rodzina - prywatność - intymność. Dzieje rodziny polskiej w kontekście europejskim. Sympozjum na XVII Powszechnym Zjeździe Historyków Polskich (Kraków 15-18 września 20o4). Zbiór studiów, red. D. Kałwa, A. Walaszek, A. Żarnowska, Warszawa 2006, s. 181-19o.

Kersten K., Historyk - twórcq źródet, „Kwartalnik Historyczny”, 1971, nr 2, s. 313-329.

Kersten K., Relacje jako typ źródła historycznego, [w:] Pamiętnik X Powszechnego Zjazdu Historyków Polskich w Lublinie 17-21 września 1968 r. Referaty plenarne. Sekcje VII-XI, Warszawa 1968, s. 316-329.

Kierzkowski M., Historia mówiona - próba definicji podejścia, „Wrocławski Rocznik Historii Mówionej”, R. 4 (2014), s. 5-20.

Kierzkowski M., Źródła ustne (audiowizualne) w kontekście badań historycznych. Próba metodologicznego oglądu statusu relacji ustnych, Wrocław 2008.

Konecki K.T., Studia $z$ metodologii badań jakościowych. Teoria ugruntowana, Warszawa 2000.

Kościelniak L., Moroń E., Historia migana - między narracją a przekładem. Uwagi metodologiczne do zbierania i opracowywania relacji osób niesłyszących, „Wrocławski Rocznik Historii Mówionej", R. 7 (2017), s. 35-67.

Kudela-Świątek W., Odpamiętane. O historii mówionej na przykładzie narracji kazachstańskich Polaków o represjach na tle narodowościowym i religijnym, Kraków 2013.

Kurkowska-Budzan M., Antykomunistyczne podziemie zbrojne na Białostocczýnie. Analiza współczesnej symbolizacji przeszłości, Kraków 2009.

Kurkowska-Budzan M., Bajka o Kopciuszku - oral history, [w:] Historia zwyktych ludzi. Współczesna angielska historiografia dziejów społecznych, 2003, s. 177-187.

Kurkowska-Budzan M., Historia zwyktych ludzi. Współczesna angielska historiografia dziejów społecznych, Kraków 2003.

Kurkowska-Budzan M., Ile cukru w cukrze, czyli ile historii w historii mówionej?, [w:] Klio na wolności. Historiografia dziejów najnowszych po 1989 roku, red. M. Kruszyński [et al.], Lublin 2016, s. 117-124.

Kurkowska-Budzan M., Informator, świadek historii, narrator : kilka wątków epistemologicznych $i$ etycznych oral history, „Wrocławski Rocznik Historii Mówionej”, R. 1 (2011), s. 9-34.

Kurkowska-Budzan M., Stasiak M., Stadion na peryferiach, Kraków 2016.

Machcewicz A., Bunt. Strajki w Trójmieście. Sierpień 1980, Gdańsk 2015.

Paczkowski A., Historyk dziejów najnowszych wśród źródet, [w:] Historia - dziś. Teoretyczne problemy wiedzy o przeszłości, red. E. Domańska, R. Stobiecki, T. Wiślicz, Kraków 2014, s. 143 -160 (ebook). 
Rakowski T., Historia mówiona i źródta etnograficzne jako „wiedza pewna”. Przypadek potransformacyjnej historii Torgutów w zachodniej Mongolii oraz historii wsi Broniów w centralnej Polsce, „Rocznik Antropologii Historii”, R. 5 (2015), s. 59-90.

Stolarz A., „Dzielenie się pamięciq”. Praktyka i teoria historii mówionej, Lublin 2016.

Strzembosz T., Akcje zbrojne podziemnej Warszawy 1939-1945, Warszawa 1978.

Strzembosz T., Odbijanie i uwalnianie więźniów w Warszawie 1939-1944, Warszawa 1972.

Strzembosz T., Oddziały szturmowe konspiracyjnej Warszawy 1939-1945, Warszawa 1979.

Strzembosz T., Szare Szeregi jako organizacja wychowawcza, Warszawa 1981.

Strzembosz T., Z przygód historyka polskiej konspiracji wojskowej 1939-1945, [w:] Ojczyzna i wolność. Prace ofiarowane Profesorowi Janowi Ziótkowi w siedemdziesiata rocznicę urodzin, red. A. Barańska, W. Matwiejczyk, E. Ziółek, Lublin 20oo, s. 681-709.

Szpak E., „Chory człowiek jest wtedy jak coś go boli”. Społeczno-kulturowa historia zdrowia i choroby na wsi polskiej po $1945 r$., Warszawa 2016.

Szpak E., Mentalność ludności wiejskiej w PRL. Studium zmian, Warszawa 2013.

Thompson P., Gtos przeszłości. Historia mówiona, [w:] Teoria wiedzy o przeszłości na tle wspótczesnej humanistyki, red. E. Domańska, Poznań 2010, s. 281-294.

Thompson P., The Edwardians. The Remaking of British Society, London 1975.

Thomson A., Four Paradigm Transformations in Oral History, „The Oral History Review”, t. 34 (2007), nr 1, s. 49-70.

Topolski J., Jak się pisze i rozumie historię. Tajemnice narracji historycznej, Warszawa 1998.

White H., Znaczenie narracyjności dla przedstawiania rzeczywistości, [w:] Poetyka pisarstwa historycznego, red. E. Domańska, M. Wilczyński, 2010, s. 135-17o.

Wolff-Powęska A., Polskie spory o historię i pamięć. Polityka historyczna, „Przegląd Zachodni”, 2007, $\mathrm{nr}$ 1, s. 3-44.

Wrzosek W., Źródło historyczne jako alibi realistyczne historyka, [w:] Historyk wobec źródet. Historiografia klasyczna i nowe propozycje metodologiczne, red. J. Kolbuszewska, R. Stobiecki, Łódź 2010, s. 22-38.

Wylegała A., Przesiedlenia a pamięć. Studium (nie)pamięci społecznej na przykładzie ukraińskiej Galicji i polskich „ziem odzyskanych”, Toruń 2014. 
This article addresses the issue of the use of oral accounts in research on very recent history. In particular, the topic of interest is the question of whether oral history in its current form (i.e., given its theoretical, practical, and institutional settings) has a realistic chance of playing a significant role in the shaping of the practice of historical research in Poland. The starting point for addressing this problem is the increasing rate of debate in the academic community, in particular in the field of historiography and the perspectives for its development as a component of academic reflexion. This text contains an attempt at both the identification of the key factors hindering the use of oral accounts in historical research and the formulation of a proposal to deal with impasses.

Keywords: oral history, the recent history of Poland, the history of historiography, the historical method, historical sources
Marcin Stasiak

"So, Therefore, Were We and Are We Naive...?" One More Contribution to the Debate on the Use of Oral Accounts in Research into the Most Recent History of Poland 